\title{
MANAJEMEN PENDIDIKAN PAUD IT YAYASAN NURUL AMALIAH BALIKPAPAN
}

\author{
Prita Indriawati \\ Universitas Balikpapan \\ pos-el: prita.indria@uniba-bpn.ac.id
}

\begin{abstract}
ABSTRAK
Jenis penelitian yang dilakukan oleh peneliti adalah penelitian deskriptif kualitatif, yang bertujuan untuk mengetahui bagaimana perencanaan, pengorganisasian; pengarahan, dan pengendalian manajemen pendidikan di PAUD IT Yayasan Nurul Amaliah Balikpapan. Sumber data dalam penelitian ialah menggunakan purposive sample yaitu orang-orang yang peneliti anggap dapat memberikan informasi mendalam mengenai Manajemen Pendidikan di TK PAUD IT Yayasan Nurul Amaliah Balikpapan. Teknik pengumpulan data yang digunakan dalam penelitian ini meliputi: (1) Teknik Observasi, (2) Teknik Wawancara, dan (3) Dokumentasi. Sedangkan keabsahan data dalam sebuah penelitian kualitatif sangatpenting. Ada empat kriteria yang digunakan dalam menetapkan keabsahan data yaitu terdiri dari derajat kepercayaan (credibility), (2) keteralihan (transferability) dan (3) kebergantungan (dependability), dan (4) kepastian (confirmability). Hasil penelitian tentang Implementasi Manajemen Pendidikan di PAUD IT Yayasan Nurul Amaliah Balikpapan dapat disimpulkan bahwa perencanaan, pengorganisasian, pengarahan, dan pengendalian manajemen pendidikan yang dilakukan guru dan kepala sekolah di PAUD IT Yayasan Nurul Amaliah Balikpapan telah berjalan dengan baik sesuai dengan fungsi manajemen pendidikan.
\end{abstract}

Kata kunci : Manajemen Pendidikan, PAUD IT.

\section{ABSTRACT}

The type of research conducted by researchers is descriptive qualitative research, which aims to know how planning, organizing; direction, and control of education management in PAUD IT Nurul Amaliah Foundation Balikpapan. Sources of data in the study is to use purposive sample that is the people who researchers assume can provide in-depth information about Management Education in TK PAUD IT Nurul Amaliah Foundation Balikpapan. Data collection techniques used in this study include: (1) Observation Techniques, (2) Interviewing Techniques, and (3) Documentation. While the validity of data in a qualitative research is very important. There are four criteria used in establishing the validity of data that consists of the degree of trust (credibility), (2) transfers (transferability) and (3) dependability, and (4) certainty (confirmability). The result of research on Implementation of Education Management in PAUD IT Nurul Amaliah Balikpapan Foundation can be concluded that planning, organizing, directing and controlling of education management in PAUD IT Nurul Amaliah Balikpapan Foundation has been run well in accordance with education management function.

Keywords: Education Management, PAUD IT.

\section{PENDAHULUAN}

Undang-Undang Republik Indonesia Nomor 20 tahun 2003 Tentang Sistem Pendidikan Nasional pasal 1 Ayat 1 menyatakan bahwa, pendidikan adalah usaha sadar dan terencana untuk mewujudkan suasana belajar dan proses pembelajaran agar peserta didik aktif mengembangkan potensi dirinya untuk memiliki kekuatan spiritual atau keagamaan, pengendalian diri, kepribadian, kecerdasan, akhlak mulia, dan keterampilan yang diperlukan dirinya, masyarakat, bangsa, dan negara. Dari pengertian diatas merupakan acuan pendidikan nasional untuk mencerdaskan bangsa dan negara, karena 
kemajuan suatu bangsa dapat dilihat dari segi pendidikan warga negaranya.

Untuk memajukan pendidikan adalah dengan cara meningkatkan kualitas pada pendidikan yang mengacu pada standar nasional pendidikan yang harus dipakai sebagai tolok ukur dalam pengembangangan pendidikan. Menurut Undang-Undang Republik Indonesia Nomor 20 Tahun 2003 tentang Sistem Pendidikan Nasional dan PP. No. 19 Tahun 2005 tentang Standar Nasional Pendidikan, yang menyatakan bahwa, "Standar nasional pendidikan terdiri atas standar isi, proses, kompetensi lulusan, tenaga pendidik dan kependidikan, sarana dan prasarana, pengelolaan, pembiayaan, dan penilaian pendidikan yang harus ditingkatkan secara berencana dan berkala". Standar Nasional Pendidikan (SNP) dimaksudkan untuk memacu penyelenggara, pengelola, dan satuan pendidikan agar dapat terus meningkatkan kualitas dan kinerjanya dalam memberikan pelayanan pendidikan yang bermutu. Pendidikan yang bermutu dapat tercapai apabila pengelola pendidikan dapat menyediakan fasilitas dan sumber daya pendidikan yang berkualitas.

Sejalan dengan hal tersebut Permendikbud 137 Tahun 2014 menyatakan bahwa, standar Pendidikan Anak Usia Dini (PAUD) terdiri atas 8 standar, yaitu: standar tingkat pencapaian perkembangan anak, standar isi, standar proses, standar penilaian, standar pendidik dan tenaga kependidikan, standar sarana prasarana, standar pengelolaan dan standar pembiayaan. Maka lembaga pendidikan PAUD dalam menyelenggarakan pendidikan harus mempunyai manajemen yang baik sesuai dengan standar yang telah ditetapkan pemerintah, agar dapat mewujudkan tujuan utama pendidikan anak usia dini yaitu membantu meletakkan dasar perkembangan sikap/perilaku, pengetahuan, keterampilan serta daya cipta yang sangat diperlukan anak dalam menyesuaikan diri dengan lingkungan, bagi pertumbuhan dan perkembangan anak selanjutnya pada pendidikan di sekolah dasar.

Dalam penelitian sebelumnya, skripsi yang ditulis oleh Bustami (2012) berjudul Manajemen Pendidikan PAUD Al- Fath Sabang yang bertujuan untuk mengetahui implementasi manajemen pendidikan yang dilakukan oleh PAUD tersebut, hasil dari penelitian tersebut adalah manajemen di PAUD Al- Fath Sabang telah disusun dengan baik. Hal tersebut tercermin dari: (a) Perencanaan program kegiatan pendidikan dengan menyusun rencana kegiatan, sesuai dengan ketentuan; (b) Pelaksanaan pendidikan di PAUD Al-Fath telah diarahkan pada proses pembelajaran berjalan dengan baik, efektif dan menyenangkan; dan (c) Pengawasan dilakukan dengan dua sistem pengawasan yaitu: pengawasan atasan langsung dan pengawasan fungsional. Pengawasan atasan langsung dilakukan oleh kepala sekolah, sedangkan pengawasan fungsional dilakukan oleh pengawas sekolah.

Secara sederhana implementasi dapat diartikan pelaksanaan atau perencanaan, Majone dan Wildavsky (Nurdin dan Usman, 2002: 68), mengemukakan implementasi sebagai evaluasi. Browne dan Wildavsky (Nurdin dan Usman, 2004: 70), mengemukakan bahwa "Implementasi adalah perluasan aktivitas yang saling menyesuaikan.

Menurut Mustari (2014:1) "Manajemen adalah sebuah proses dalam perencanaan untuk mencapai tujuan tertentu". Sedangkan manajemen pendidikan adalah suatu kegiatan yang berupa proses pengelolaan, kerja sama sekelompok manusia yang tergabung dalam organisasi pendidikan, untuk mencapai tujuan pendidikan yang telah ditetapkan sebelumnya, agar efektif dan efisien" (Mustari 2014: 5). 
Sedangkan menurut Daryanto \& Farid (2013: 1) manajemen dapat diartikan, dalam arti luas dan arti sempit manajemen dalam arti luas adalah perencanaan, pengorgaisasian, pengarahan dan pengendalian (P4) sumber daya organisasi untuk mencapai tujuan secara efektif dan efisien. Sedangkan penjelasannya mengenai manajemen pendidikan didefinisikan sebagai seni dan ilmu mengelola sumber daya pendidikan untuk mewujudkan suasana belajar dan proses pembelajaran agar peserta didik secara aktif dapat mengembangkan potensi dirinya untuk memiliki kekuatan spiritual keagamaan, pengendalian diri, kepribadian, kecerdasan, akhlak mulia, serta keterampilan yang diperlukan dirinya, masyarakat, bangsa dan negara.

Berdasarkan uraian di atas dapat diartikan bahwa manajemen adalah suatu proses yang sistematis dalam melakukan pengelolaan sumber daya pendidikan untuk mewujudkan suasana belajar dan proses pembelajaran yang dimiliki oleh sekolah atau organisasi untuk mencapai tujuan yang telah ditentukan dengan mengembangkan potensi dirinya dan memanfaatkan sumber daya yang ada pada sekolah atau organisasi tersebut.

Fungsi manajemen menurut pendapat Masyhud (2014:128) terdiri dari fungsi perencanaan, fungsi pengorganisasian, fungsi pengkordinasian, fungsi penggerakan (motivasi), fungsi pengawasan, dan fungsi penilaian.

Tujuan dan manfaat manajemen pendidikan menurut Daryanto \& Farid (2013: 2) antara lain: (1)Terwujudnya suasana dan proses pembelajaran yang aktif, kreatif, efektif, menyenangkan dan bermakna; (2) Terciptanya peserta didik yang aktif mengembangkan potensi dirinya untuk memiliki kekuatan spiritual keagamaan, pengendalian diri, kepribadian, kecerdasan, akhlak mulia, serta keterampilan yang diperlukan dirinya, masyarakat bangsa dan Negara; (3) Terpenuhinya salah satu dari lima kompetensi tenaga kependidikan; Tercapinya tujuan pendidikan secara efektif dan efisien; dan (5) Terbekalinya tenaga kependidikan dengan teori tentang proses dan tugas administrasi pendidikan.

Berikut ini merupakan urgensi manajemen terhadap bidang manajemen pendidikan: (1) Manajemen Kurikulum yang merupakan rencana dan pengaturan mengenai tujuan, isi dan bahan dalam pembelajaran serta cara yang digunakan sebagai pedoman penyelenggaraan kegiatan belajar mengajar; (2) Manajemen Peserta didik merupakan individu yang mendapat pelayanan pendidikan sesuai dengan bakat, kemampuan agar tumbuh dan berkembang dengan baik; dan (3) Manajemen Tenaga Pendidik dan Kependidikan meliputi guru, maupun non guru. Berdasarkan UU No. 14 tahun 2005, Kompetensi tersebut adalah kompetensi pedagogik, personal/kepribadian, sosial, dan professional.

Manajemen pendidikan TK menurut Hapidin (2013: 1.7) adalah "suatu usaha mengelola semua kegiatan termasuk proses interaksi edukatif antara anak didik dengan pendidik dan lingkungannya secara terencana, teratur, dan sistematis untuk mencapai tujuan". Tujuan manajemen pendidikan PAUD dapat dicapai dengan cara mengefisienkan biaya pengeluaran, penggunaan sumber daya lainnya dan mengefektifkan langakah-langkah dalam mengambil setiap keputusan sehingga tujuan lembaga tersebut dapat tercapai.

Penelitian yang dilakukan oleh Sholihah dengan pendekatan penelitian kualitatif dengan rancangan studi kasus yang difokuskan pada perencanaan saran dan prasarana, pengadaan sarana dan prasarana, dan pemeliharaan sarana dan prasarana di TK Aisyiyah Bustanul Atfal Takerharjo Solokuro 
Lamongan Sumber informasi diperoleh dari kepala sekolah, para guru, siswa, serta masyarakat orang tua siswa dan pihak terkait lainnya menyimpulkan bahwa perencanaan, pengadaan dan pemeliharaan saran dan prasarana cukup baik.

\section{METODE PENELITIAN}

Jenis penelitian yang dilakukan oleh peneliti adalah penelitian deskriptif kualitatif, yang bertujuan untuk mendiskripsikan bagaimana perencanaan, pengorganisasian; pengarahan, dan pengendalian manajemen pendidikan di PAUD IT Yayasan Nurul Amaliah Balikpapan. Subyek penelitian ini adalah Kepala Sekolah dan Guru PAUD IT Yayasan Nurul Amaliah Balikpapan.

Menurut Lofland (Moleong, 2014: 157) "sumber data utama dalam penelitian kualitatif ialah kata-kata dan tindakan, selebihnya adalah data tambahan seperti dokumen dan lain-lain", selanjutnya Moleong (2014: 224) mengatakanbahwa "pada penelitian kualitatif tidak ada sampel acak, tetapi sampel bertujuan (purposive sample)". Sumber data dalam penelitian ialah menggunakan purposive sample yaitu orang-orang yang peneliti anggap dapat memberikan informasi mendalam mengenai Manajemen Pendidikan di PAUD IT Yayasan Nurul Amaliah Balikpapan.

Teknik pengumpulan data yang digunakan dalam penelitian ini meliputi: (1) Teknik Observasi, (2) Teknik Wawancara, dan (3) Dokumentasi. Sedangkan keabsahan data dalam sebuah penelitian kualitatif sangatpenting. Menurut Moleong (2014) bahwa, ada empat kriteria yang digunakan dalam menetapkan keabsahan data yaitu terdiri dari derajat kepercayaan (credibility), (2) keteralihan (transferability) dan (3) kebergantungan (dependability), dan (4) kepastian (confirmability).

\section{HASIL DAN PEMBAHASAN}

\section{Implementasi Manajemen Kurikulum} di PAUD IT Yayasan Nurul Amaliah Balikpapan

Pemahaman tentang konsep dasar manajemen kurikulum merupakan hal yang terpenting bagi para Kepala Sekolah yang kemudian merupakan modal untuk membuat keputusan dalam implementasi kurikulum yang akan dilakukan oleh para pendidik.

Manajemen kurikulum yang diterapkan di PAUD IT Yayasan Nurul Amaliah Balikpapan adalah melalui proses perencanaan, pengorganisasian, pengarahan dan pengendalian melalui evaluasi. Tahapan dalam perencanaan yang dilakukan meliputi perencanaan pembuatan kurikulum berserta penjabarannya.

Kurikulum yang akan direncanakan sesuai dengan kebutuhan para pendidik dan peserta didik di PAUD IT Yayasan Nurul Amaliah Balikpapan. Kurikulum yang dikembangkan berdasarkan kurikulum 2006, di mana kurikulum ini disebut juga KTSP (Kurikulum Tingkat Satuan Pendidikan). Artinya sekolah sebagai tingkat terkecil-lah yang dapat merancang sendiri kurikulum pendidikannya. Dengan tidak mengenyampingkan tingkat perkembangan anak usia dini yang menjadi peserta didik di PAUD IT Yayasan Nurul Amaliah Balikpapan, yaitu tingkat A dan B serta rombel (rombongan belajar) yang akan diampu oleh masingmasing pendidik.

Kurikulum yang telah dikembangkan melalui RKH (Rencana Kegiatan Harian), RKM (Rencana Kegiatan Mingguan), 
yang merupakan penjabaran dari pemetaan prota (program tahunan), prosem (program semester).

Perencanaan kegiatan belajar melalui proses isi dari kurikulum itu sendiri. Maksudnya perencanaan yang telah dilakukan di PAUD sudah melalu tahap perencanaan yang matang. Dapat dilihat dari penjabaran pemetaan menjadi program tahunan kemudian menjadi program semester, setelah itu rencana kegiatan mingguan dan rencana kegiatan harian.

Perencanaan yang disesuaikan dengan kebutuhan tingkat perkembangan anak, dalam hal ini tingkat (kelompok) A dengan rentang usia 2-3 tahun atau tingkat (kelompok) B dengan rentang usia 3-4 tahun. Hal ini dikarenakan juga indikator yang akan dilaksanakan pun berbeda setiap tingkatan. Masing-masing pendidik membuat perencanaan kurikulum yang akan dilaksanakan. Kerjasama antar pendidik sangat dibutuhkan.

Perlu pula penyusunan jadwal kegiatan anak didik selain tahapan kegiatan pembelajaran yang biasa dilakukan di PAUD IT Yayasan Nurul Amaliah Balikpapan. Penyusunan jadwal tersebut meliputi kegiatan ekstrakurikuler sebagai kegiatan yang dapat mengembangkan minat dan bakat anak. Kemudian jadwal pelaksanaan kegiatan pembalajaran tambahan. Kegiatan tambahannya adalah pembelajaran agama Islam. Untuk memperkuat hasil dari kegiatan keagamaan tersebut, setiap diawal kegiatan pembelajaran, anak didik akan duduk bersama membuat lingkaran sesuai agamanya untuk berdoa bersama. Dibimbing oleh pendidik yang telah ditunjuk.

Selanjutnya, tema-tema yang dikembangkan sebagai bahan pembelajaran saling terkait antara satu dengan yang lain. Dengan demikian pendidik dapat lebih banyak mengembangkan keterkaitan antara tema tersebut. Setelah dilaksanakan kurikulum, seperti tersebut di atas dijabarkan melalui proses perencanaan, pengorganisasian, koordinasi, kemudian implementasi dan pengendalian. Pada tahap pengendalian dilakukan evaluasi oleh Kepala PAUD dalam mengimplementasikan kurikulum yang telah digunakan, baik terhadap pendidik maupun anak didik. Misalnya pada Rencana Kegiatan Harian (RKH), maka akan dilakukan evaluasi sebagai tolak ukur dari pelaksanaan kegiatan tersebut, peserta didik dievaluasi oleh pendidik dan Kepala PAUD mengevaluasi Pendidik dalam bentuk monitoring atau supervisi kelas.

Penilaian yang dilakukan pendidik terhadap peserta didik berbentuk penilaian harian yang dirangkum dalam penilaian satu semester. Tetapi setiap triwulan akan disampaikan kepada orang tua/wali peserta didik, agar mengetahui perkembangan putra/putrinya. Adapun penilaian tersebut dalam bentuk narasi bukan berupa angka tetapi dengan menggunakan sImbol bintang.

\section{나 (BB) Belum Berkembang}
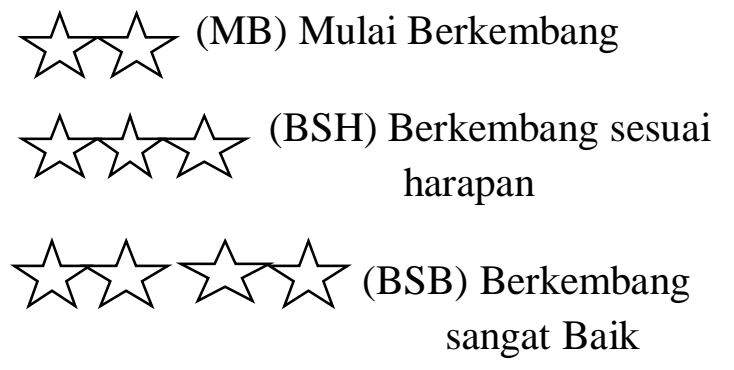

Evaluasi terhadap anak didik yang dilakukan oleh pendidik, adalah melalui pengamatan/observasi dan pencatatan 
anecdot record, penugasan, percakapan, unjuk kerja dan hasil karya anak. Semua hasil evaluasi yang dilakukan oleh pendidik dirangkum dalam penilaian yang disebut rangkuman penilaian setiap bulannya dan dirangkum kembali dalam satu semester atau enam bulan. Rangkuman penilaian inilah yang menjadi acuan dalam pengisian BLP (Buku Laporan Perkembangan) anak didik di PAUD IT Yayasan Nurul Amaliah Balikpapan.

Dengan demikian manajemen kurikulum yang diterapkan di PAUD IT Yayasan Nurul Amaliah Balikpapan telah memenuhi tahapan-tahapan dalam pengembangan dan implementasi di lingkungan PAUD itu sendiri. Hal ini bertujuan agar hasil pencapaian dari manajemen kurikulum itu sendiri mencapai hasil yang maksimal dan memuaskan bagi pihak sekolah, orang tua dan mampu meningkatkan perkembangan anak didik.

\section{Implementasi Manajemen Peserta Didik di PAUD IT Yayasan Nurul Amaliah Balikpapan}

Sebagai wadah atau wahana peserta didik untuk mengembangkan diri seoptimal mungkin, baik yang berkenaan dengan segi-segi individualitas, segi sosial, aspirasi, kebutuhan dan segi-segi potensi peserta didik lainnya, di bawah ini adalah fungsi dari manajemen peserta didik.

Penerimaan peserta didik di PAUD IT Yayasan Nurul Amaliah Balikpapan merupakan suatu proses pencarian, menentukan dan menarik peminat yang akan menjadi peserta didik untuk tahun ajaran yang akan berlangsung. Penerimaan peserta didik ini, ditentukan daya tampung
PAUD, syarat administrasi dan syarat lainnya yang harus dipenuhi.

PAUD IT Yayasan Nurul Amaliah Balikpapan atas seiijin pengurus Yayasan Nurul Amaliah dalam pembentukan panitia tersebut yang beranggotakan seluruh pendidik PAUD. Dengan adanya panitia ini maka proses perekrutan akan mudah dilaksanakan dan berjalan lancar. Kepanitiaan yang telah dibentuk disahkan oleh Ketua Yayasan dengan membuatkan Surat Keputusan Yayasan Nurul Amaliah, sebagai bukti penetapan panitia penerimaan peserta didik baru dan menjadi dasar hukum pelaksanaan tugas panitia.

Panitia memulai dengan kooordinasi pembagian tugas kemudian pembuatan promosi/pengumuman penerimaan peserta didik baru dengan memasang spanduk di daerah yang strategis dan di depan pagar sekolah, penyebaran brosur, pemberitahuan secara langsung kepada warga sekolah dan komite sekolah PAUD IT Yayasan Nurul Amaliah Balikpapan.

Menetapkan rencana penerimaan sesuai dengan hasil rapat bersama pengurus Yayasan Melati dan syaratsyarat yang harus dipenuhi/dilampirkan oleh orang tua peserta didik yang mendaftarkan putra-putrinya. Syarat tersebut antara lain, copy akta kelahiran, pas foto kedua orang tua/wali ukuran $4 \times 6$ masing-masing 1 (satu ) lembar, copy kartu keluarga (satu lembar), copy KTP (satu lembar), usia peserta didik dan mengisi formulir pendaftaran serta membayar biaya pendaftaran pengganti pembuatan map pendaftaran dan copy formulir pendaftaran.

Sebagai informasi kepada semua pihak khususnya calon orang tua/wali.peserta didik di lingkungan PAUD IT Yayasan Nurul Amaliah dan sekitarnya, maka panita yang telah 
terbentuk memasang pengumuman berupa pemasangan spanduk penerimaan peserta didik baru secara terbuka. Pemasangan spanduk tersebut dipasang sekitar jalan yang strategis yang menuju PAUD IT Yayasan Nurul Amaliah Balikpapan dan di depan pagar sekolah.

Disebarkan pula brosur penerimaan peserta didik baru, yang di dalamnya terdapat syarat dan ketentuan pendaftaran, informasi kontak yang dapat dihubungi, beberapa prestasi yang telah dicapai sekolah, foto kegiatan peserta didik dan pendidik, program PAUD dan selayang pandang tentang PAUD.

Jika batas pendaftaran telah habis waktunya tetapi daya tampung belum terpenuhi maka panitia dipersilakan memperpanjang waktu penerimaan sebelum kegiatan tahun ajaran baru berlangsung. Begitu juga sebaliknya, jika daya tampung peserta didik PAUD IT Yayasan Nurul Amaliah Balikpapan telah terpenuhi maka dengan sendirinya panitia akan menutup pendaftaran walaupun batas waktu penerimaan peserta didik baru masih ada, dikarenakan daya tampung masing-masing kelas atau kelompok telah ditentukan yaitu satu orang pendidik mengampu 10-15 peserta didik.

Hal ini dilakukan atas kebijakan Kepala PAUD IT Yayasan Nurul Amaliah Balikpapan, mengingat keterbatasan ukuran ruang (hanya $6 \mathrm{x} 4 \mathrm{~m}$ ), agar lebih mudah dalam pelaksanaan kegitan pembelajaran dan kegiatan lebih efektif sehingga tujuan pembelajaran dan kemajuan tingkat perkembangan anak akan mudah tercapai.

PAUD IT Nurul Amaliah juga memberikan pembinaan melalui kegiatan parenting bersama ahlinya, yaitu suatu kegiatan pertemuan antara pendidik, orang tua/wali peserta didik dan ahli/psikolog.
Jika tenaga ahli tidak ada maka Kepala PAUD menggantikan sebagai narasumber. Layanan lainnya adalah, layanan perpustakaan, di mana para peserta didik dapat memanfaatkan untuk menambah wawasan dan pengetahuan melalui bukubuku yang telah disiapkan.

Untuk kesehatan, PAUD IT Yayasan Nurul Amaliah Balikpapan juga memberikan layanan kesehatan melalui kerjasama dengan pihak Puskesmas Mekar Sari Balikpapan, seperti kegiatan Pembinaan Hidup Bersih dan Sehat (PHBS). Di samping itu pula pendidik setiap minggu keempat akan menimbang, mengukur tinggi badan dan mengukur lingkar kepala peserta didik. Setelah itu dicatat pada KMS (Kartu Menuju Sehat) masing-masing peserta Didik.

\section{Implementasi Manajemen Tenaga Pendidik dan Kependidikan di PAUD IT Yayasan Nurul Amaliah Balikpapan}

Untuk hal tersebut diperlukan manajemen pendidik yang dilakukan di PAUD IT Yayasan Nurul Amaliah Balikpapan adalah sebagai berikut :

\section{a. Perencanaan}

Pendidik direncanakan sesuai kebutuhan di PAUD IT Yayasan Nurul Amaliah Balikpapan. Oleh sebab itu perekrutan pendidik tidak selalu dilakukan setiap tahun Ajaran Baru. Kepala PAUD akan memberikan laporan dan usulan kepada pengurus Yayasan Nurul Amaliah, jika diperlukan tenaga baru. Atas Rekomendasi Kepala PAUD itulah pertimbangan Yayasan akan diambil sebagai suatu keputusan.

Beberapa syarat yang harus dipenuhi oleh calon pendidik di PAUD IT Yayasan Nurul Amaliah Balikpapan, antara lain :

1. Sehat jasmani dan rohani

2. Berakhlak mulia 
3. Memiliki komitmen untuk menjunjung tinggi profesinya

4. Mematuhi tata tertib pendidik

5. memiliki latar belakang pendidikan sebagai pendidik atau memiliki kualifikasi S1/D4 Keguruan/Paud (Jika belum memiliki S1, maka diwajibkan untuk meneruskan jenjang S1.

\section{b. Pengorganisasian}

Pelaksanaan proses pembelajaran dibutuhkan pengorganisasian pendidik untuk mencapai tujuan pembelajaran dan tujuan pendidikan yang akan di capai. Oleh karena itu pengorganisasian sangat penting, agar pendistribusian /pembagian tugas pendidik menjadi jelas dan bertanggungjawab.

Masing-masing pendidik mendapat tugas dan tanggungjawab yang sama dalam pengelolaan pembelajaran dan tanggungjawab di kelompok yang diampu. Pembagian tugas ini dikuatkan dengan dikeluarkannya Surat Keputusan Pembagian Tugas setiap tahun ajaran baru. Terkadang terjadi roling kelas di anatara pendidik dengan tujuan memberikan suasana baru, pengalaman baru dan motivasi bekerja serta belajar menerima tantangan baru.

\section{c. Pelaksanaan}

Pelaksanaan pembelajaran membutuhkan pendidik dalam pengelolaan pembelajaran itu sendiri. Oleh karenanya dimulai dari perekrutan, pembagian tugas dilanjutkan dengan pelaksanaan tugas sebagai pendidik. Begitu juga seorang Kepala PAUD juga harus melaksanakan tugas dan kewajibannya sebagai pemimpin, administrator, manajer, supervisor, motivator dan inspirator bagi pendidik di lingkungan sekolah.

\section{d. Pengawasan}

Pengawasan sangat diperlukan di dalam pelaksanaan pendidikan di sekolah. Dengan adanya pengawasan ini maka terlihat adanya pengendalian dan monitoring baik secara langsung maupun tidak langsung. Secara langsung maksudnya adalah pendidik oleh Kepala PAUD dalam mengemban tugas dan kewajibannya baik di dalam kelas maupun di luar kelas dan melaksanakan supervisi kelas yang dilakukan sesuai dengan jadwal yang telah ditentukan. Biasanya supervisi di PAUD IT Yayasan Nurul Amaliah Balikpapan dilaksanakan di awal tahun pelajaran minggu kedua, selanjutnya setiap triwulan selama satu tahun pelajaran.

Kepala PAUD melakukan monitoring pelaksanaan validasi yang diikuti oleh pendidik setiap enam bulan sekali (setiap semester ganji dan genap). Sedangkan pengawasan secara tidak langsung adalah pengawasan yang dilakukan kepala PAUD terhadap pendidik tanpa direncanakan. Maksudnya sewaktu-waktu Kepala PAUD IT Yayasan Nurul Amaliah Balikpapan dapat mengunjungi beberapa saat setiap Kelompok/Kelas tentang proses pembelajaran yang sedang berlangsung.

\section{e. Pembinaan}

Adapun beberapa kegiatan pembinaan bagi pendidik sebagai berikut : (a) micro teaching, (b) pelatihan di dalam sekolah, (c) pelatihan di luar sekolah, (d) sharing, dan (e) kegiatan membaca. 


\section{KESIMPULAN}

Hasil penelitian tentang Implementasi Manajemen Pendidikan di PAUD IT Yayasan Nurul Amaliah Balikpapan dapat disimpulkan bahwa perencanaan, pengorganisasian, pengarahan, dan pengendalian manajemen pendidikan di PAUD IT Yayasan Nurul Amaliah Balikpapan telah berjalan dengan baik sesuai dengan fungsi manajemen pendidikan.

\section{DAFTAR PUSTAKA}

Bustami. (2012) Manajemen Pendidikan PAUD AL-Fath Sabang. Diambil dari: http://ejournal.unp.ac.id/index.php /paud/article/view file/1668/1437

Daryanto \& Farid, (2013). Konsep Dasar Manajemen Pendidikan di Sekolah Yogyakarta: Gava Media

Hapidin,dkk. (2013) Manajemen Pendidikan TK. Banten:Universitas Terbuka

Mohamad M, ManajemenPendidikan . Jakarta: PT. Rajawali Pers.

Moleong, L. J. (2014) Metode Penelitian Kualitatif (Edisi Revisi). Bandung: Remaja Rosdakarya.

Mukhtar. (2013) Metode Praktis Penelitian Deskriptif Kualitatif. Jakarta: Referensi Gaung Persada Press Group.

Masyhud S. (2014) Manajemen Profesi Kependidikan Yogyakarta: Kurnia Kalam Semesta

Sagala, S. (2013) Manajemen Strategik dalam Peningkatan Mutu Pembelajaran Bandung: Alfabeta.

Sholihah (2014). Manajemen Sarana dan Prasarana di TK Aisyiyah Bustanul Atfal Takeharjo Solokuro Lamongan. Diambil dari: http://ejournal.unesa.ac.id/index.p $\mathrm{hp} /$ inspirasi

Sofiyati (2012). Implementasi PrinsipPrinsip Manajemen Pendidikan Islam dalam Manajemen Persekolahan.
Diambil dari: http://ejournal.upi.edu/.../01_implem entasi_prinsip-prinsip_Manajemen.

Undang-Undang No. 20 Tahun 2003, Sistem Pendidikan Nasional Indonesia.

Usman (2011). Manajemen. Jakarta: Bumi Aksara. 